\title{
Tendenser i fodboldspillet socialpsykologisk set
}

\author{
af Arne Pedersen
}

På det seneste har opmærksomheden været rettet mod fodboldspillet. I første række på grund af de tragiske episoder, som knytter sig til hooliganfænomenet og lægtervolden. Interessen i denne artikel retter sig først og fremmest mod den vold, som finder sted på selve spillepladsen.

De medieformidlede brutale overfald på Ewald Lienen, Antonioni og Battiston blev bevæggrunde til at drage paralleller fra fodboldspillets internationale udstillingsvindue til hjemlige forhold. I et forsøg på at få verificeret, om den samme udvikling også kunne spores i dansk fodbold, gennemførtes en spørgeskemaundersøgelse blandt fodbolddommere i Frederiksborg amt (Fodboldvold - hvorfor? Pedersen, A. og Rasmussen G. Københavns Universitet 1984).

Dommernes beskrivelse af den moderne fodboldspiller kan sammenfattes således: Spillerne mangler respekt for autoriteten. Spillerne har ingen disciplin; de er ikke vant til at være underlagt en autoritet, er ikke vant til konsekvens; er ikke blevet opdraget. De ser en fordel $i$ at protestere og mangler endvidere respekt over for modspillerne.

Af dommernes indberetninger til DBU ang. antallet af voldelige frispark, fremgår det klart, at tendensen også findes i dansk fodbold. Det, der primært er af interesse, er det ,uforklarlige“ frispark, som udelukkende begås i den hensigt at stoppe en modstander. Det frispark, der følger som en konsekvens af, at de risici, der er ved at udføre en bestemt handling, tilsyneladende vælges bort. Det frispark, der begås med fuldt overlæg og som i teorien kunne være valgt ugjort.

Det er en pointe, at den slags frispark ikke begrænser sig til at finde sted $i$ mere betydningsfulde kampe, hvor der er store penge og prestige på spil. Det betyder naturligvis ikke, at f.eks. sejrsbonus og pressens behandling af idrætten er uden betydning for hyppigheden og arten af forseelserne.

Men der sker en nedsivning, og betydningen af at vinde (ikke tabe) kan være lige så fatal for en sekundaspiller som for en topprofessionel.

Gerningsmanden til sådanne frispark betragtes enten som abnorm (ubegribelig) og udelukkelsen er den eneste mulighed; eller som et produkt af uheldige miljømæssige omstændigheder - modtagelig for div. former for 
terapeutiske tiltag. Fælles for de to forklaringstyper er, at ingen af dem kan forklare den empirisk konstaterbare stigning i volden.

Det er en grundantagelse her, at en historisk, kritisk analyse af de samfundsmæssige forhold er det nødvendige udgangspunkt også for en begribelse af fænomenet fodboldvold; men inden en problematisering af dommernes ensidige beskrivelse af „,fodboldspilleren“, skal der redegøres for det moderne fodboldspils kortvarige historie, som både $i$ tid og rum er sammenfaldende med industrialiseringen i England i slutningen af forrige århundrede.

\section{Historie}

I denne periode sker der en systematisering af almuens ældgamle, voldsomme og kaotiske ,,pøbelfodboldspil“", som hidtil har været udøvet på gader og stræder. Det er via kostskolerne, den første stramning finder sted. Der gives direktiver for spillets udøvelse på en begrænset, og på forhånd fastlagt bane. I sin kostskoleform er spillet forbeholdt overklassen, men efterhånden, som arbejdstiden gradvis nedsættes, bl.a. som flg. af fagforeningernes arbejde, får de øvrige samfundsmedlemmer også mulighed for at dyrke det nye spil.

I og med industrialiseringens enorme indflydelse på samfundslivet, sker der en opbrydning af vante arbejds-, samlivs- og boforhold. Den nye tids industriarbejder, bosat $i$ de store byer, er ,,fri“ $i$ en helt anden forstand end tidligere. Samfundet har derfor brug for ændrede styrings- og socialiseringsmekanismer.

På den baggrund er det forståeligt, at overklassens modstand mod fodboldspillets udbredelse er kortvarig, idet spillet netop kan ses som et socialiseringsinstrument, hvis indflydelse øges ved spillernes frivillige deltagelse i aktiviteten.

Fodboldspillets regler og normer er formulerede og prægede af samfundets herskende moral. Ved at deltage i spillet indlæres en villighed til at være underlagt en autoritet uden at sætte spørgsmålstegn ved, hvor denne autoritet stammer fra. Der indøves i at indgå i samarbejde om en ,,meningsløs" aktivitet, samtidig med, at denne aktivitet finder sted efter den abstrakte klokketid; hvor det sociale samvær tidligere var karakteriseret ved en mere organisk tidsfornemmelse.

\section{Karaktertyper}

De karakteridealer, som ligger til grund for det daværende samfund, er bl.a. beskrevet af David Riesman. Han bruger ordet ,indrestyring" som en 
betegnelse for tidens socialkarakter. Det typiske for denne karakter er, at tidligt indpodede religiøse adfærdsmæssige normer og værdier indlæres så kraftigt, at de ",gyroskopisk" kan styre individet gennem hele tilværelsen. Psykologisk set sker dette ved opbyggelsen af et stærkt overjeg. Ved samfundsmæssigt at kunne bestemme indholdet $i$ overjeget og evt. løbende justere dette indhold f.eks. gennem fodboldspillets normer og regelsæt, kunne den samfundsmæssige integration sikres.

Fodboldspillet har siden starten for godt 100 år siden ikke undergået fundamentale ændringer. Der er blevet opbygget et organisatorisk og bureaukratisk system omkring det, således, at det for den enkelte spiller er umuligt at få indflydelse på regler og andre forhold omkring spillet.

Samfundsudviklingen har ikke på samme måde stået stille. Den første industrielle revolution fulgtes af den anden, og nu, $\mathrm{i}$ automatiseringens epoke, forandres livsbetingelserne i et endnu hurtigere tempo.

Det samfundsmæssige individ, som eksisterer på de nuværende betingelser, beskriver Riesman som andrestyret. Billedligt er gyroskopet blevet afløst af ,radaren" som det vigtigste navigationsinstrument gennem tilværelsen. Hvor den tidligere omtalte indrestyrede personlighed var karakteriseret ved neurotiske personlighedstræk, er det ikke klart afgrænsede symptomer, som karakteriserer den nye, andrestyrede karakter, som i stedet må beskrives ved mere diffuse - grænsepsykotiske - symptomer. For Riesman er det afgørende, at det nye individ udvikler en form for narcissisme, som dybest set har mere med angst end med stolthed at gøre; som mere er præget af sløret konkurrence end af åben rivalisering.

Teorierne bag narcissismebegrebet har deres udspring hos Freud, men det er især de nutidige videreudviklinger af disse teorier, som har vundet udbredelse $i$ beskrivelsen af det moderne individ og samfund.

Den narcissistiske karakter opstår som følge af et mangelfuldt udviklingsforløb. Barnet får ikke stillet sådanne udviklingsbetingelser til rådighed, at overgangen fra én udviklingsfase til den næste kan ske på en optimal måde.

Barnets lystoplevelser og fantasier er først knyttet til fundamentale biologiske processer omkring optagelse og udstødelse af føde. Det befinder sig $i$ den primære narcissistiske tilstand og oplever sig selv som almægtigt.

Når barnet $\mathrm{i}$ tiltagende grad oplever, at almagtsfølelsen ikke er reel i forhold til omgivelsernes krav, indkorporeres kravene i personligheden på vejen mod et mere realistisk selvbillede.

Det er narcissismeteoretikernes påstand, at denne udvikling ikke kommer til at forløbe på en rimelig måde i det moderne samfund, hvorfor barnet ikke gennemløber den ødipale fase optimalt - den fase, der er så afgørende for overjegsdannelsen, som er medvirkende til at "styre" individet gennem tilværelsen. 
Når det ikke lykkes at komme „,helskindet " gennem denne periode, skyldes det ikke mindst, at det moderne samfund har medvirket til en opsplitning af familien. Barnet får således ikke, via afpassede krav og samlivsrelationer, mulighed for at erstatte de primære narcissistiske almagtsforestillinger med reelle forestillinger og krav, som omgivelserne stiller det overfor. I stedet for at forholde sig til den usikre og uigennemsigtige verden, dannes sekundære narcissistiske forestillinger om eget værd, samtidig med, at realiteternes uafviselige pres, momentvis medvirker til afmagtsforestillinger og depressivitet.

\section{Forandringer i spillet}

Det hidtil anførte peger således på en „usamtidighed" mellem spillets førindustrielle normer og de moderne udøveres ,,normer". Normsammenstødet har $\mathrm{i}$ idrættens, og dermed også $\mathrm{i}$ fodboldens verden betydet store ændringer $\mathrm{i}$ forholdet til konkurrencemomentet, reglerne og dommeren.

Hvor fodboldspillet tidligere var karakteriseret af holdånd, er der ikke længere denne gruppeloyalitet til at moderere konkurrencen; hvor idrætten før opmuntrede til samarbejde mellem holdkammerater og indførte regler for fairplay, er disse samtidig med, at de også forherligede den, brudt sammen, således at konkurrencen associeres med bundløs aggression, og spillerne finder det vanskeligt at fatte en konkurrencesituation, som ikke leder direkte til mordtanker.

Den nye karaktertypes ambivalente forhold til konkurrencens resultat: sejren eller nederlaget, medfører tillige en anden ændring af spillet, idet hovedvægten i de taktiske overvejelser ofte kommer til at ligge på sikkerhed og resultatorientering, hvilket betyder, at der bliver mindre og mindre plads til spillets iboende legmoment. Det spontane, det dristige, det chancebetonede får mindre og mindre råderum med det resultat, at spillets ekspressive værdi formindskes: færre og færre tilskuere.

Spillernes forhold til reglerne har også undergået forandringer. Fodboldspillet, som må karakteriseres som en regelleg, har netop vundet sin popularitet og evne til at fascinere ved sine enkle, gennemsigtige og uforanderlige regler.

Til sammenligning kan det nævnes, at de samfundsmæssige regler (love etc.) ikke har denne „evighedskarakter", men netop er undergivet forandringens lov, ja netop skabes som følge af stemning, holdninger og politiske udsving i samfundet. Sådanne love kan og skal ændres gennem samfundsborgernes virksomhed. Der er ingen tvivl om, at den moderne fodboldspiller har meget svært ved at se denne forskel mellem de love, han møder i f.eks. 
hjem og skole, og de regler, hvorunder spillet skal udfolde sig. Som dommerne siger, har spillerne ingen respekt for lovene; som på den anden side er gode nok, bare de andre overholder dem.

Spillerne overfører så at sige den opfattelse, de har af love og regler, skabt i det moderne samfund på det, i denne sammenhæng gamle spil, hvilket betyder, at heller ikke dette spils regler og autoriteter er fredet længere. Problemet er bare, at hvis spillets regler brydes for markant og for ofte, så brydes grundlaget for legen. Så er der ikke længere tale om fodbold, så er spillet gået til grunde i anarki og vold.

Der spilles stadigvæk fodbold, men tendentielt kan de ovenstående argumenter have gyldighed. I hvert fald medvirker den brutalisering af spillet, som er set de senere år, til en svækkelse af tilgangen til spillet.

Med hensyn til spillernes forhold til autoriteten, dommeren, er det ikke specielt denne, de har problemer med. Dommeren er blot i mange tilfælde den første åbenlyse autoritet, de møder. Han kan ikke besnakkes og påvirkes gennem de sædvanlige diskussioner, en færdighed, som er blevet opøvet tidligere i hjem og skole, hvor ,,autoriteten “ i mange tilfælde er skjult, og hvor andrestyringens konformisme træder $i$ stedet for forældrenes autoritet. Spillernes selvopfattelse trues således af dommerens absolutte magt. De får problemer med det af realiteterne konfronterede selvbillede.

\section{Træneren}

Spørgsmålet er imidlertid, om ikke træneren i langt højere grad er spillets reelle autoritet. I en artikel i Centring (1985/1), har jeg, sammen med Geert Rasmussen, søgt at redegøre for de psykologiske relationer, som må antages at være virksomme i denne sammenhæng. Kort kan det nævnes, at vi bl.a. på baggrund af Stanley Milgrams berømte socialpsykologiske eksperimenter, har foretaget en analyse af trænerens mulighed for at udøve indflydelse på spillerne. Konklusionen, som hos Milgram, er, at spillerne er villige til at gå meget langt for at følge trænerens direktiver.

\section{Toppræstationer}

Enhver, som har spillet fodbold, og som fortsat har interesse for spillet ved, at de færdigheder, elitefodboldspilleren mestrer, er resultatet af en lang række faktorer. Således ligger der intens træningsindsats bag.

Spillerne har haft gavn af de faciliteter, samfundet gratis stiller til deres rådighed, og mange eksperter har arbejdet med dem. Der ligger altså en 
langvarig forberedelse bag de toppræstationer i form af elegante driblinger, velplacerede langskud, afleveringer etc. spilleren yder.

På samme måde kunne det hævdes, at der bag spillets alvorlige forseelser (de negative ,toppræstationer") ligger lang tids træning og forberedelse. Ja, forberedelsestiden til sådanne præstationer begynder allerede ved spillerens fødsel og hænger sammen med den tiltagende samfundsskabte fjendtlighed i de mellemmenneskelige relationer.

Ud fra en sådan opfattelse bliver de grove frispark ikke uforståelige. Tværtimod kommer de til at fremtræde som logiske konsekvenser af de forhold, spillerne udvikles under. Tillige fremtræder gerningsmanden ikke længere som en undtagelse, som abnorm; vi har alle $\mathrm{i}$ vekslende grad modtaget træning mod den negative toppræstation. Kun mere eller mindre individuelt betingede forhold er afgørende for i hvilket felt ,,toppræstationen" kommer til at ligge.

\section{En anden teori}

Af det ovenfor anførte fremtræder der et meget determineret menneskesyn. Individet er udleveret til de skiftende omstændigheder og præges helt afgørende i de tidlige barndomsår. Individet er for en sådan forståelse et socialiseringsresultat, som kun i mindre grad gennem f.eks. psykoanalyse eller andre terapier kan forandres.

Der findes imidlertid en anden teori om udviklingen af den menneskelige karakter. Med udgangspunkt i Marx' dialektiske udsagn: samfundet skaber mennesket, men mennesket skaber på sin side samfundet, udvikles en langt mere positiv teori for udviklingen af den menneskelige karakter. I denne forståelse svinder betydningen af de tidlige leveår $i$ det omfang individet udvikler sig i og med nye krav og betingelser. I stedet for at være udleveret til betingelserne former individet selv aktivt sin karakter.

Fodboldspillet får på denne baggrund en anden betydning, og spillet, som indledningsvis blev affærdiget med en rolle som socialiseringsagent for det borgerlige samfund, kan også ses som en mulighed for de unge til at udvikle færdigheder, som er nødvendige for at kunne magte tilværelsen i samfundet, færdigheder, som i øvrigt kun vanskeligt øves i familien og skolen.

Der er ikke noget odiøst $i$, at man kan give sig ind under en autoritet $i$ den tid en fodboldkamp varer, eller at kunne indgå $i$ et mellemmenneskeligt samvær uden at føle sin identitet truet; men, som det er søgt demonstreret, har det moderne individ sværere ved at gøre disse ting end tidligere tiders autoritetstro individer.

Der må således gøres mere ud af at forklare de unge fodboldspillere noget 
om forskellen på spilleregler og samfundets „,spilleregler“, noget om dommerens rolle overhovedet. Sådanne tiltag kan virke idealistiske og i modstrid med antagelsen om samfundets store betydning for karakterudviklingen. Imidlertid drejer det sig for fodboldspillets vedkommende om drenge på 5-6 år, hvis personlighed endnu ikke er færdigdannet. Derfor kan betydningen af gode trænere, som må være opmærksomme på disse forhold, ikke overvurderes, således, at blodtørstige pubertetsdrenge og fanatiske forældre kan afskaffes som trænere for de yngste fodboldspillere.

\section{Afs/utning}

Der er omtalt to historiske karaktertyper, eksemplificerede ved Riesmans indrestyring og andrestyring. Her mod slutningen kan man spørge, hvilken karaktertype kan spille fodbold uden at sætte integriteten over styr, uden at foretage negative toppræstationer?

Den andrestyrede karakters ,,problem“ er manglen på et rimeligt overjeg, således, at karakteren ikke fuldstændig udleveres til tidens tendenser og. holdninger. På den anden side har den indrestyrede karakter et overjeg, som er for rigidt og hæmmende.

Riesman peger - utopisk - på, hvad han kalder den autonome karakter, som rummer en afbalanceret dynamik mellem personlighedens tre instanser, hvor jeget er i stand til at integrere idets og overjegets impulser på en harmonisk måde.

En sådan personlighed vil ikke føle sin integritet truet ved at indgå i en aktivitet, hvor autoriteten for en stund afgives til en fodbolddommer. Evt. fejlkendelser og andre hændelser vil heller ikke true selvopfattelsen.

\section{Litteratur:}

Brüchner, P. Kapitalismens socialpsykologi. 1974.

Lasch, C. The Culture of Narcissism. 1980.

Milgram, S. Lydighedens Dilemma. 1977.

Pedersen, A. og Rasmussen, G. Fodboldvold -Hvorfor? Københavns Universitet. 1984.

Pedersen, A. og Rasmussen, G. Loyalitet og vold i Fodbold. i: Centring 1985/1

Riesman, D. Det ensomme massemenneske. 1969. 
